\title{
NEW AND UNDESCRIBED GENERA AND SPECIES OF WEST AFRICAN NOCTUIDAE.
}

\author{
BY W. J HOLLAND, PH.D., PITTSBURGH, PENN.
}

Methorasa, Moore.

I. M. complicata, sp. nov. §. Front olivaceous-brown; collar olivaceous margined with pale green internally. Upper side of thorax and abdomen fuscous; lower side of thorax, abdomen, and legs dark cinereous. The primaries are dark brown traversed with exceedingly complicated lines of pale silvery-green, the most conspicuous markings being a silvery dot at the origin of the radial nervule, two small subapical silvery marks upon the costa, below which is a $<-$ shaped silvery band, pointing inwardly toward the base. There are narrow zigzag and irregularly curved transverse basal, subbasal, median, limbal, and submarginal light lines. The secondaries are dark fuscous except on the costa near the base, where they are whitish, shining. On the under side, the primaries are fuliginous with the inner margin near the base whitish, shining. Upon the costa beyond the middle and before the apex are transverse white linear dots, and a short whitish linear streak about the middle of the outer margin conformed to the course of the third median nervule. The secondaries on the under side are cinereous, profusely sprinkled with blackish scales, with a well defined discal dot, a curved and dentate transverse median line and three or four blackish dots on the outer margin near the apex. Expanse, $33 \mathrm{~mm}$.

2. M. cornus-copiae, sp. nov. ठ. Front, collar, upper side of thorax and abdomen dark chocolate-brown. Anal tuft of hairs grayish. Lower side of thorax and abdomen dark brown. Legs concolorous with the tarsi grayish, indistinctly ringed with darker brown. The fore wings are dark blackish- brown with an obscure series of submarginal paler markings; on the median area just below the costa there is a narrow silvery line describing a semi-circle, and below it still another similar line uniting with the upper line at its outer end by a narrow silvery straight line, the whole roughly forming the outline of a horn of plenty. The secondaries on the upper side are uniformly dark fuscous. On the lower side the primaries are fuliginous, slightly paler on the outèr margin, marked with a whitish dot at the end of the cell, and a narrow whitish transverse linear streak on the costa before the apex. The secondaries are gray, with the costa and an incomplete submarginal band dark brown. These wings are also ornamented by a well defined sub-oval discal dot. Expanse, $23 \mathrm{~mm}$.

3. $M$. eximia, sp. nov. ठ․ Palpi on the lower side pale cinereous. Front dark brown. Collar and patagia dark brown, margined externally by paler brown; upper side of thorax blackish-brown; upper side of abdomen fuscous. Lower side of thorax gray. Legs dark gray with the ends of the tibiae and the ends of the joints of the tarsi whitish. Lower side of abdomen fuliginous. The upper side of the primaries is dark brown along the costa and from the base as far as the middle of the wing. The outer margin is paler brown. The dark area toward the base is separated from the lighter marginal area by an oblique irregularly curved narrow silvery-white line, and the inner dark area is broken up into spots by narrow silvery sub-basal and median lines, which coalesce with narrow silvery lines running along the nervules, and descending from the costa. The most conspicuous of 
the dark spots thus included by narrow silvery lines are a subtriangular spot on the costa before the apex, and a subrhomboid spot beyond the end of the cell. The secondaries are dark fuscous on the upper side. On the under side, the wings are pale fuscous traversed by broad submarginal bands of dark fuscous. The primaries have a dark fuscous subquadrate spot beyond the end of the cell. The secondaries are marked on the cell by a black basal ray, widening outwardly, terminating abruptly, and followed by a well defined blackish dot, beyond which is a zigzag incomplete transverse limbal line of dark brown below the enlarged end of the discal ray. There is an incomplete median band of dark brown running parallel to the outer margin, but terminating before it reaches the inner margin. Expanse, $50 \mathrm{~mm}$.

\section{Plusia, Fabr.}

4. P. mapongua, sp. nov. §. Palpi sooty-gray. Head cinereous; collar brown margined internally with pale cinereous. Patagia, thorax, and abdomen above and below grayish-ochraceous; the abdominal tufts dark gray. Legs dark gray with the tarsi ringed with whitish. The primaries are dark vandyke brown on the middle area with the outer and inner margins paler, reflecting in certain lights a pale golden-green lustre. There are two silvery dots at the base, one on the costa, and one near the middle of the wing, followed by a narrow irregularly curved transverse basal line of pale flesh color, margined on both sides by dark brown. Beyond this on the median area are two broad silvery spots, the innermost the larger, subovoid, the outermost smaller and circular. At the point where these two silvery spots almost touch, there is a dark brown elongated elliptical spot, which extends upward beyond the end of the cell. At its upper extremity lying on the costa before the apex is a pale flesh colored spot, shading within and without into pale vandyke brown, and margined on the lower side by a semi-circular black dash. There is a narrow waved transverse limbal and a similar angulated transverse marginal line. The fringes are whitish, spotted with black at the apex and about the middle of the outer margin, and checked with narrow lines of blackish at the tips of the nervules. The secondaries are fuscous with an obscure discal spot just beyond the end of the cell. The fringes are concolorous, slightly lighter at the apex and the anal angle. On the under side the primaries are dark fuscous with the inner margin and a subtriangular spot below the cell whitish. There are a few small white dots on the costa before the apex, and an obscure incomplete transverse limbal band of darker fuscous extending from beyond the middle of the costa toward the middle of the inner margin. The secondaries have the outer half broadly bordered with dark fuscous, shading into cinereous near the anal angle. There is a distinctly defined discal spot at the end of the cell. Expanse, $27 \mathrm{~mm}$.

5. P. siculifera, sp. nov. $\delta$. Front, upper side of thorax and abdomen obscure brown; lower side of abdomen and legs paler brown. The primaries have the middle area clouded with dark blackish brown, which is produced outwardly about the middle of the wing to the margin as a broad blackish ray. This dark tract of color in certain side lights gives a brilliant golden reflection. From the inner margin at the base there extends upwardly a band of silvery tinged with flesh color, which reaches the costa and about the middle sends forth a branch, which extends outwardly and then abruptly downwardly toward the outer angle, terminating about the middle of the wing. This band is sickle-shaped. In addition there are some silvery basal markings, an elongated transverse subapical band on the costa, and some spots along the outer margins. The secondaries are uniformly dark fuscous with the fringes paler. On the under side, both wings are dark fuscous with the basal half of the secondaries paler. Expanse, $24 \mathrm{~mm}$. 
6. P. Ogovana, sp. nov. 万. Front, thorax, and abdomen above and below brownish-fuscous. The primaries are dark woodbrown, in certain lights reflecting a cupreous sheen. They are covered with a multitude of dark brown minute reticulations and are marked by zigzag sub-basal and limbal transverse line. The latter line which is faint and dark brown, is bordered on either side by parallel pale lavender lines, and at the upper extremity near the costa on the inner side is a large triangular dark brown spot, and on the outer margin a broad similarly colored submarginal band. Both the large brown spot and the broad brown band in certain lights display a brilliant coppery lustre. There are some light spots on the margin most conspicuous about the middle. The fringes are pale brown checkered with darker brown, and between the first and second median nervules about the middle of the wing is a minute silvery V-shaped spot. The secondaries on the upper side are dark fuscous, paler at the base, with the rnargins lighter. On the under side, both wings are pale fuscous with the outer margins broadly blackish. The fringes are pale; there are a few light spots on the costa before the apex, and a distinct discal spot at the end of the cell in the secondaries. Expanse, $30 \mathrm{~mm}$.

7. P. gorilla, sp. nov. $\delta$. Head and thorax dark brown; abdomen above slightly paler brown; lower side of thorax and abdomen fuscous. The primaries are dark sootybrown, with a coppery reflection beyond the cell on the middle of the outer third of the wing. There are some obscure transverse basal, median, and limbal bands. The secondaries are uniformly dark fuscous. On the under side, both wings are dark fuscous with the outer half fuliginous, shading into cinereous upon the outer margin. Expanse, 26 $\mathrm{mm}$.

This is one of the most obscurely colored species of the genus.

\section{Plusiopalpa, gen. nov.}

Allied to Plusia, from which it may be at once distinguished by the palpi, which are long, produced, curving upwardly, and heavily clothed with long scales; the last joint is very little shorter than the second joint, flattened laterally, and produced at the apex upon its anterior margin as a minute point, or spur. The abdomen on the upper side is conspicuously tufted. The third pair of legs is relatively longer than in Plusia. The primaries are rounded at the apex and are not produced at the outer angle, as in a large majority of the species contained in the genus Plusia. Type Plusiopalpa dichora, Holland.

There is a specimen of this insect unnamed in the British Museum, from Java.

8. P. dichora, sp. nov. $\delta$. Front and collar wood-brown; upper side of thorax dark brown; abdomen mouse color with two large dark brown tufts of raised hair on the dorsal line just behind the thorax and a smaller similar tuft of mouse colored hair on the middle of the abdomen. The lower side of the body and legs is slightly paler than the upper side. The primaries are brown with a broad triangular patch on the outer margin reflecting a coppery lustre. There are three or four dark brown, or blackish, basal dashes followed by a pale curved sub-basal line, succeeded by a broad dark brown shade covering the middle of the wing, defined externally and internally by irregular transverse median and transverse limbal lines of pale chocolatebrown. The middle of this shade is marked by a broad longitudinal black ray running from the middle of the wing toward the middle of the outer margin and ornamented near its inner extremity by a fine U-shaped silvery mark, which is succeeded externally by a minute silvery dot. The marginal tract which reflects most distinctly the coppery lustre is defined inwardly by a narrow curved blackish line, curved once just below the apex and then describing a semi-circle, the lower end 
of which terminates a little before the outer angle. The fringes are pale brown minutely checkered with dark brown. The secondaries are pale fuscous, marked by an obscure incomplete transverse median band. On the under side both wings are fuscous; the primaries have the costa pale ochraceous sprinkled with minute brown dots; both wings have the outer margins pale cinereous; both are crossed by a broad submarginal blackish band, irregularly angulated externally, defined internally by a broad and almost straight dark brown line; both wings have a discal dot at the end of the cell. Expanse, $37 \mathrm{~mm}$.

\section{Plusiotricha, gen. nov.}

Allied to Plusia. The palpi are slightly more prominent than in Plusia; the third joint stouter. The antennae are filiform, nearly as long as the costa of the primaries. The abdomen has enormously developed hairy brushes located laterally upon the posterior segments extending backwardly and outwardly and appressed at their extremities to the very long widely divergent brushes of hair-like scales which clothe the outer margins of the claspers. The legs have the tibiae of the third pair armed with long and delicate spurs as in Plusia and densely clothed with hair-like scales. The primaries have the costa nearly straight, the apex produced, slightly rounded; the exterior margin and outer angle evenly rounded and the inner margin straight. The secondaries are subpyriform with the outer margin evenly rounded; the inner margin straight. Type Plusiotricha livida, Holland.

9. $P$. livida, sp. nov. $\delta$. The fore wings are obscure vandyke brown with a cupreous reflection on the outer margin. There are some black markings at the base. Beyond these is a very faint and somewhat obscure transverse basal line bordered externally near the inner margin with black, coalescing on the cell with an oblique transverse line running from the costa one-third of the distance from the base toward the outer angle, which it does not, however, reach. This line at its termin ation before the outer angle coalesces with a slightly curved limbal transverse line which runs from the costa two-thirds of the distance from the base to the inner margin before the outer angle, and is traversed throughout its extent by a narrow darker line widest on the costa. The basal portion of the triangular space included between this oblique line and the transverse limbal line is clouded with blackish brown, accentuated on its inner margin by a minute silvery dot, and near the costa by two or three black dots. Beyond the transverse limbal line the margin is broadly clouded with dark brown, followed by a fine pale submarginal curved line, which is succeeded on the middle of the margin by a triangular black spot, its apex pointing outwardly. The fringes are pale and obscurely checkered with dark brown. The secondaries are uniformly fuscous with the fringes paler, shading into whitish at the anal angle. On the under side, both wings are obscure fuscous; both are crossed by very broad blackish submarginal bands; both have the margins pale cinereous. There are a few minute ochraceous spots on the costa before the apex. The lateral tufts on the abdomen are tipped with pale ochraceous. The anal tufts are black. Expanse, 30 $\mathrm{mm}$.

\section{Deva, Walk.*}

10. D. Africana, sp. nov., ठ. Allied to $D$. auripicta, Moore, from India. Front, collar, patagia, and the upper side of the thorax maroon, with the posterior edge of the collar, and the tips and edges of the patagia marked with purplish gray scales. The upper side of the abdomen is plumbeous. The palpi are ochraceous. The lower side of the thorax and abdomen is whitish. The

* Mr. Butler refers to this genus upon structural grounds all the species in the eastern hemisphere which have hitherto been referred by authors to the genus Plusiodonta, which he restricts to the American forms. 

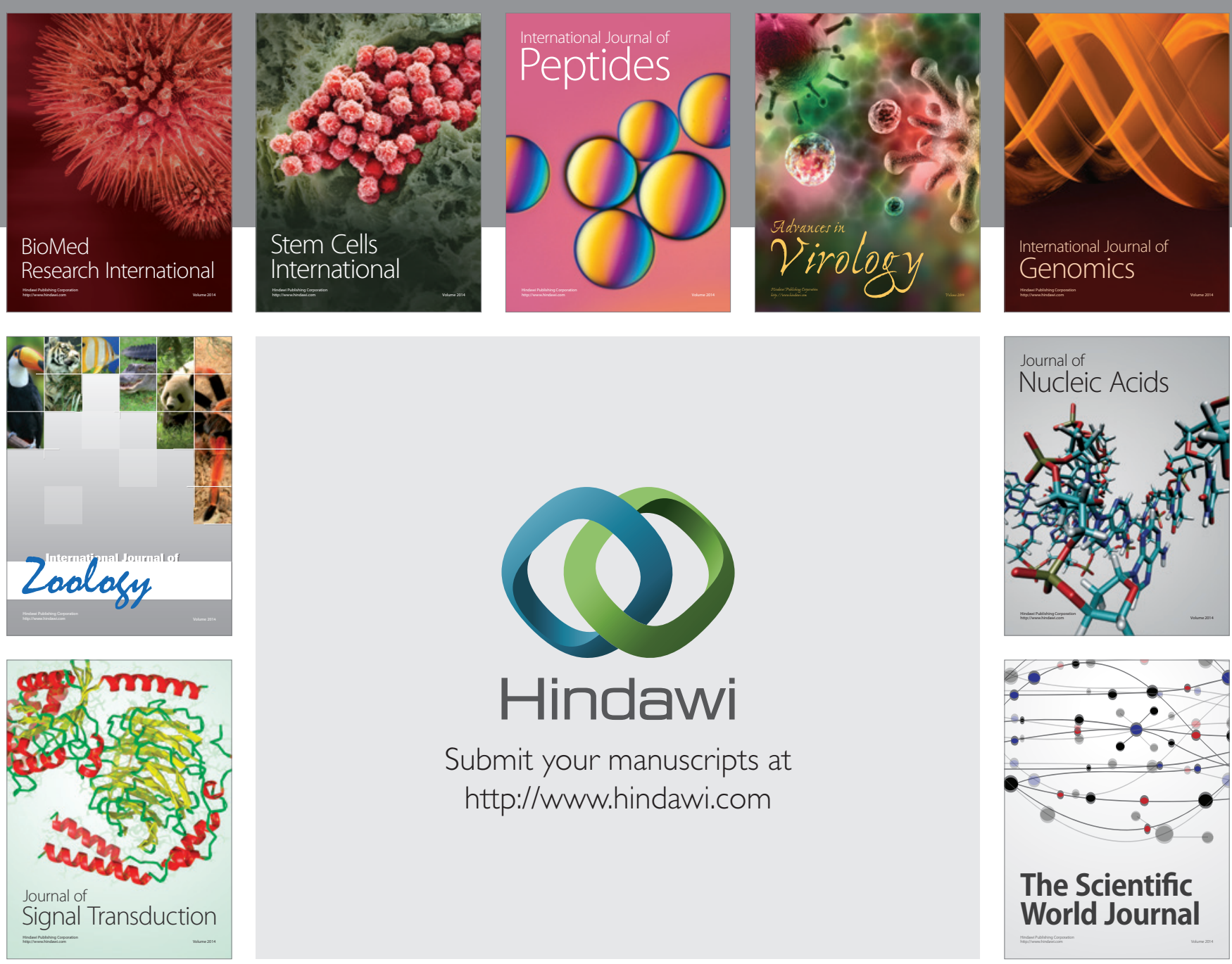

Submit your manuscripts at

http://www.hindawi.com
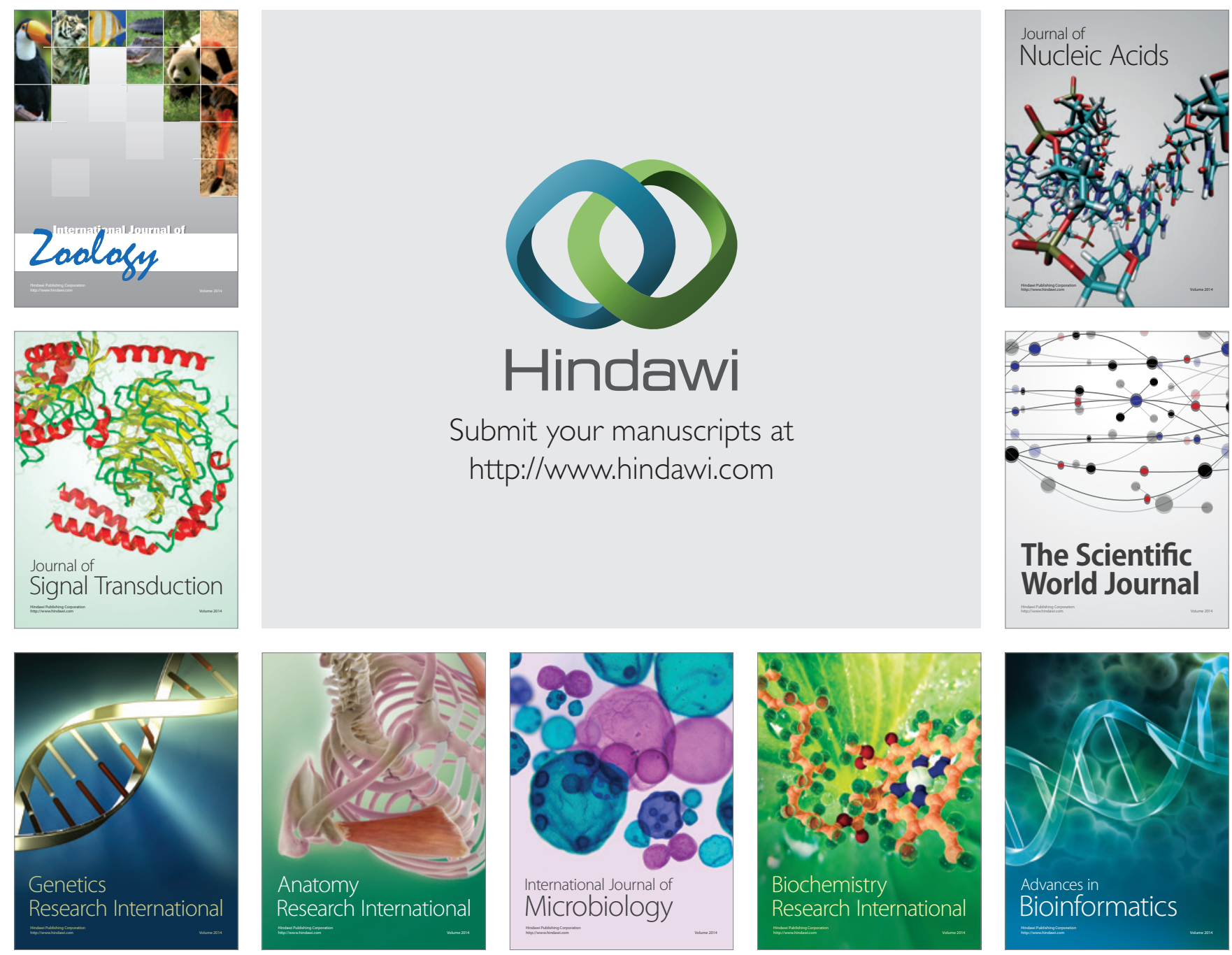

The Scientific World Journal
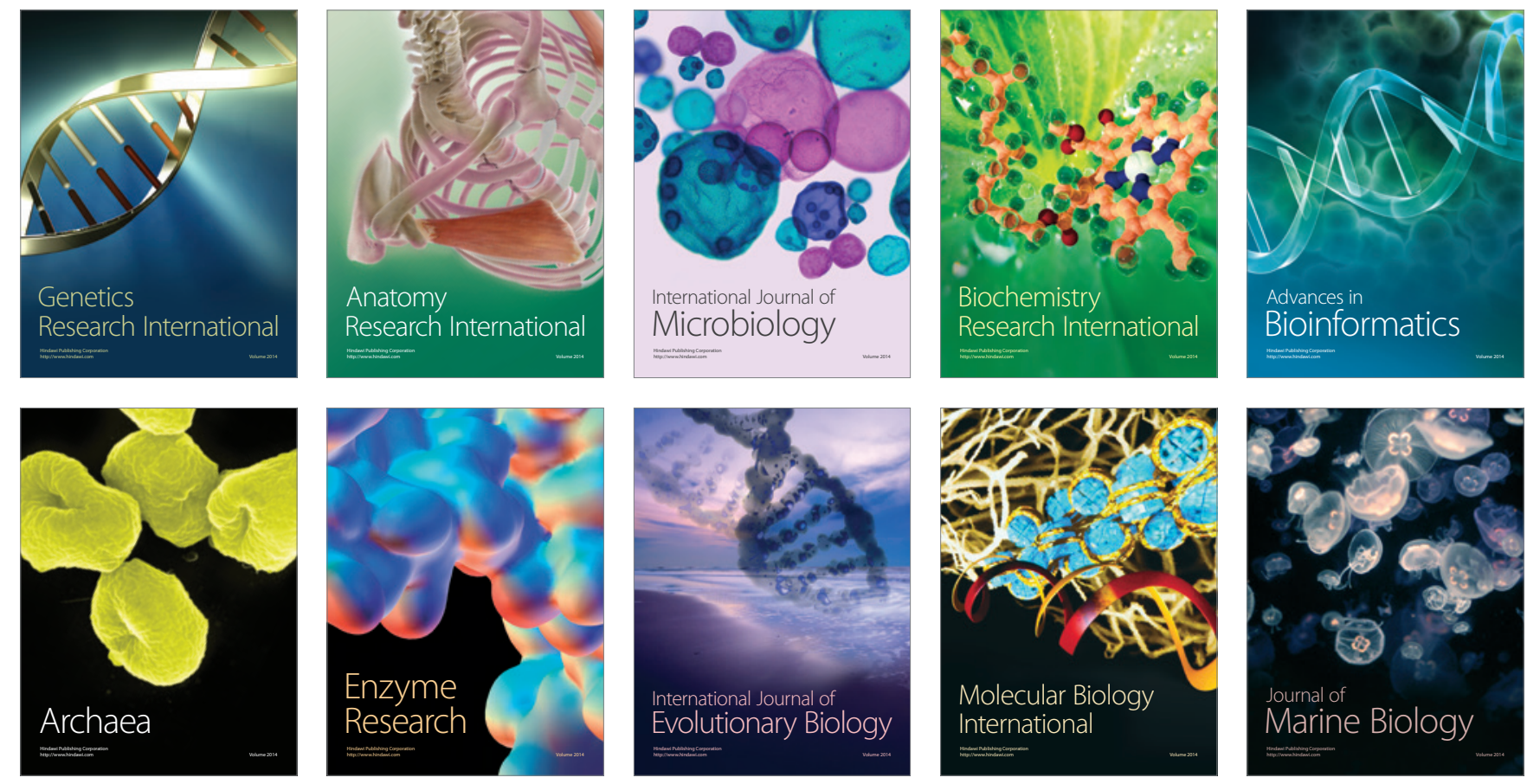